\title{
Mineraçãào
}

\section{Numerical simulation of hillside mine waste dump construction}

\author{
Simulação numérica da construção de pilhas \\ de estéril de mineração dispostas em encostas
}

\author{
Marcílio Baltazar Teixeira \\ M.Sc., PPGEM, DEMIN, \\ Escola de Minas-UFOP \\ marcilio_baltazar@hotmail.com

\section{Christianne de Lyra Nogueira \\ D. Sc., Associate Professor, PPGEM, DEMIN, \\ Escola de Minas-UFOP \\ chris@em.ufop.br}

\section{Waldyr Lopes de Oliveira Filho}

Ph.D., Associate Professor, PPGEM, DEMIN, Escola de Minas-UFOP

waldyr@em.ufop.br

\section{Resumo}

Nas atividades que envolvem armazenamento de estéril de mineração é necessária, a realização de um estudo prévio do comportamento mecânico, tanto das pilhas de estéril, quanto do terreno de fundação. Face à complexidade relacionada a esse tipo de problema, a utilização de técnicas numéricas é indispensável, ainda que forneçam uma resposta aproximada para o problema. Desta forma, apresentam-se, nesse trabalho, os resultados de uma análise tensão-deformação-resistência com base no método dos elementos finitos (MEF), de pilhas de estéril construída pelo método ascendente e dispostas em encosta. Um modelo não linear elástico perfeitamente plástico, com plasticidade associada e de acordo com o critério de resistência de Mohr-Coulomb modificado é adotado para representar o comportamento constitutivo do material empilhado, enquanto o terreno de fundação é representado por um modelo linear elástico. A técnica de "ligar a gravidade" aplicada para simular a construção de aterros via MEF é adotada, nesse trabalho, juntamente com o procedimento da malha dinâmica. As diferentes configurações geométricas, tanto das pilhas, quanto do terreno de fundação, analisadas fornecem indicação de que alguns requisitos definidos pela legislação vigente devem ser reavaliados, principalmente no que diz respeito a algumas restrições geométricas, as quais deveriam ser revisitadas e melhor especificadas.

Palavras-chave: Mineração, pilha de estéril, método dos elementos finitos.

\begin{abstract}
In activities involving disposal of mine waste in a dump, it is necessary to carry out a preliminary study of the mechanical behavior of both dump and the foundation materials. Due to the complexity of this problem, numerical techniques are essential for providing an approximate answer to the problem. Thus, the finite element method (FEM) was used to evaluate the stress-strain-strength behavior of a hillside waste dump built on a deformable foundation by the ascending method; the results of which are herein presented. The dump material is considered to be Morh-Coulomb nonlinear elastic perfectly plastic while the foundation material is considered to be linear elastic. The numerical simulation of mine waste dump construction is carried out by the "gravity turn on" technique and the dynamic mesh procedure. Different geometric configurations are analyzed and it is concluded that some requirements established by law should be reviewed and refined.
\end{abstract}

Keywords: Mining, waste dump, finite element method. 


\section{Introduction}

Fills, in general, are geotechnical works (structures), geometrically simple. However, the material can vary greatly, both in grain size (from clay to rock blocks) and state (from hard or compact to soft or loose). These landfills are usually constructed in compacted layers or not, as in the case of mine waste dumps, but can also be built hydraulically, as in tailings dams.

The physical phenomena involved in the mechanical behavior of these landfills can be simple, as in the case of landfills made by permeable and granular materials, where the effect of excess pore pressure generation during construction is neglected. It can also be extremely com- plex, as in the case of embankments made by material whose mineral constituents react with oxygen and water present in the medium, causing a thermo-chemicalhydro-mechanical coupled phenomenon (Silva, 2004, Mata et al., 2005, Guimarães et al., 2007).

This study provided the results of a stress-strain analysis of a waste mining dump built on a hillside by the ascending method without considering excess pore pressure generation during the construction process. These results are presented in this paper. This type of analysis is said to be uncoupled and considers long-term mechanical behavior (Nogueira, 1998).

The solution of the mechanical prob- lem of static equilibrium is obtained numerically by using the finite element method - FEM (Bathe, 1982), considering a plane strain condition. A nonlinear, elastic perfectly plastic, constitutive model based on modified Mohr-Coulomb strength criterion (Sloan and Booker, 1986, Abbo and Sloan, 1995) is adopted to represent the mine waste dump material while the foundation material is represented by a linear elastic constitutive model.

In order to simulate the dump construction by FEM, the technique of "gravity turn on" and the dynamic mesh procedure were adopted and both were implemented in the computer program ANLOG (Nogueira, 1998).

\section{Numerical simulation of landfill construction}

The FEM process to numerically simulate landfill construction consists of three distinct stages (Naylor et al., 1981): definition of the equivalent nodal loading due to the action of each new layer upon the others already built; definition of the rigidity of the new set of elements; and, solution of the generated algebraic equation system.

The "gravity turn on" technique is depicted in Figure 1. The effect of the new layer is simulated by applying a nodal equivalent force to the existing body forces (b) on the nodal point which belongs to this new layer. It is important to note, in this stage, that the second-layer elements
(Figure 1A) are activated.

The dynamic mesh procedure is used (Figure 1B) together with the "gravity turn on" technique. In this case, an initial mesh containing all layers is considered but with inactive elements (i. e., with restricted degrees of freedom). At each construction step, a group of elements is activated. It implies liberating their degrees of freedom and considering the element stiffness which contributes to the global stiffness of the system. Those procedures are not innovative ones. They have been introduced in several commercial softwares as PLAXIS ${ }^{\circledR}$, SIGMAW ${ }^{\circledR}$, PHASE

$$
\begin{gathered}
\hat{\mathbf{U}}_{n+1}=\hat{\mathbf{U}}_{\mathrm{n}}+\Delta \hat{\mathbf{U}}^{k} \\
\Delta \hat{\mathbf{U}}^{\mathrm{k}}=\Delta \hat{\mathbf{U}}_{\mathrm{n}}^{\mathrm{k}}+\sum_{\mathrm{k}=1}^{\text {iter }} \delta \Delta \hat{\mathbf{U}}^{\mathrm{k}}
\end{gathered}
$$

Where,

$$
\begin{aligned}
& \mathbf{K}_{\mathrm{t}} \Delta \hat{\mathbf{U}}_{\mathrm{n}}^{0}=\Delta \lambda \mathbf{F}_{\text {ext }} \\
& \delta \Delta \hat{\mathbf{U}}^{\mathrm{k}}=\left[\mathbf{K}_{\mathrm{t}}\right]^{1} \Psi^{\mathrm{k}} \\
& \Psi^{\mathrm{k}}=\mathbf{F}_{\text {ext }}^{\mathrm{k}}-\mathbf{F}_{\text {int }}^{\mathrm{k}}
\end{aligned}
$$

factor (whose sum must be unitary at the end of each construction step). The vector $\left(\mathrm{F}_{\text {ext }}{ }^{\mathrm{k}}\right)$ represents the external force
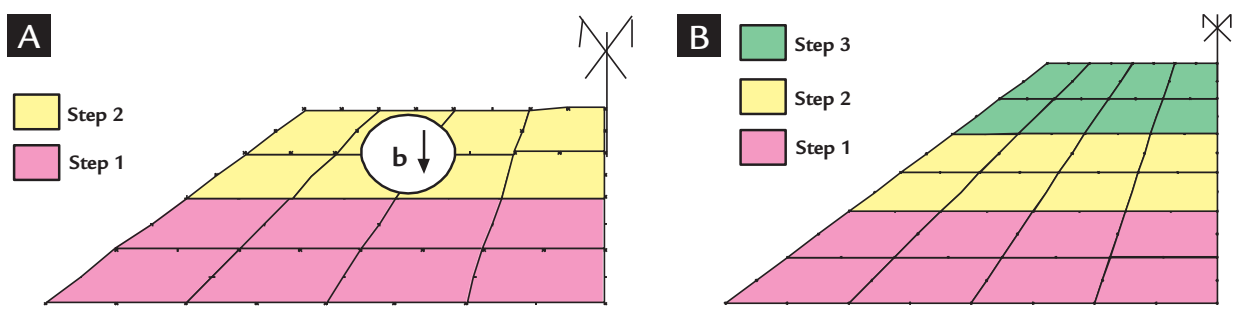

and FLAC.

At each construction step, an equation system is solved. Starting from an equilibrium configuration $n$, where the stress and strain states are known, a predicted incremental solution in terms of the global displacement $\left(\Delta \hat{\mathbf{U}}^{0}{ }_{n}\right)$ is obtained. This predicted approximation should be corrected by successive iteration $(\delta \Delta \hat{U})$ until reaching a new equilibrium configuration $n+1$ (Crisfield, 1991). In this strategy, the problem solution is obtained by updating the nodal displacement vector (U) at each new equilibrium configuration, by doing: rent step, while $\Delta \lambda$ is the load increment

and iter is the necessary iterative cycle number to reach convergence at the curA 
scheme. This vector is obtained by doing:

$$
\mathbf{F}_{\text {ext }}{ }^{k}=\mathbf{F}_{\text {ext } n}+\Delta \lambda \mathbf{F}_{\text {ext }}
$$

where $\mathrm{F}_{\text {ext }}$ represents the global arrange-

This vector is evaluated for each element that has been activated at the current

where $\Delta \mathrm{F}_{\text {int }}{ }^{\mathrm{k}}$ represents the global arrangement of the incremental internal force vec-

where $\Delta \sigma^{k}$ is the incremental stress vector evaluated at the element level of each iteration.

where $\mathbf{N}$ represents an interpolation matrix that contains the interpolation function $\mathrm{N}_{\mathrm{i}}$ that depends on the adopted element type; $\mathrm{B}$ is the cinematic matrix which depends on the strain-displacement relation; and $\mathrm{D}_{\mathrm{t}}$ is the constitutive matrix which depends on the stress-strainstrength relationship (Nogueira, 2010).

Where,

where $\Delta \hat{\mathbf{u}}^{\mathrm{k}}$ is the incremental displacement vector, at element level and updated at the current iterative cycle.

In order to describe the stressstrain-strength relationship, an elastic ment of the external nodal force due to the

$$
\mathbf{F}_{\text {ext }}^{\mathrm{e}}=\int_{V_{e}} \mathbf{N}^{\top} \mathbf{b}^{\mathrm{e}} \mathrm{dV}
$$

step. Similarly, $\mathrm{F}_{\text {int }}$ represents the internal force vector, which varies throughout the

$$
\mathbf{F}_{\text {int }}{ }^{k}=\mathbf{F}_{\text {int } n}+\Delta \mathbf{F}_{\text {int }}{ }^{k}
$$

tor on each element $\left(\Delta \mathrm{F}_{\mathrm{int}}^{\mathrm{e}} \mathrm{k}\right)$, which is evaluated in each iteration $\mathrm{k}$ and is defined as:

$$
\mathbf{F}_{\text {int }}^{e^{k}}=\int_{V e} B^{\top} \Delta \sigma^{k} d V_{e}
$$

Finally, $\mathbf{K}_{t}$ is the global stiffness matrix that represents the global arrangement of the element stiffness matrix $\left(\mathrm{K}_{\mathrm{t}}^{\mathrm{e}}\right)$ of the

$$
\mathbf{K}_{t}^{e}=\int_{V e} \mathbf{B}^{\top} \mathbf{D}_{\mathbf{t}} \mathbf{B} d V_{e}
$$

At the end of each iterative cycle, a convergence state of the solution is verified by using a criterion that relates the Euclidian norm of the unbalance force vector $\left(\Psi^{\mathrm{k}}\right)$, Equation 5, with the Euclidian norm of the external force vector, Equation 6. Thus, for a given tolerance and at each increment, the iterative scheme ensures the

$$
\Delta \sigma^{k}=\mathbf{D}_{\mathrm{t}} \Delta \varepsilon^{\mathrm{k}}
$$

$$
\Delta \varepsilon^{k}=\mathbf{B} \Delta \hat{\mathbf{u}}^{\mathrm{k}}
$$

perfectly plastic constitutive model based on modified Mohr-Coulomb criterion was adopted. This model takes into account the dilatant effect, since it considers non associate plasticity. As this model uses the same

$$
\mathbf{D}_{t}=\mathbf{D}_{\mathrm{e}}-\frac{\mathbf{D}_{\mathrm{e}} \mathbf{b}_{\mathrm{e}}\left(\mathbf{D}_{\mathrm{e}} \mathbf{a}\right)^{\top}}{\mathbf{a}^{\top} \mathbf{D}_{\mathrm{e}} \mathbf{b}_{\mathrm{e}}}
$$

body force $\mathrm{F}_{\text {ext }}^{\mathrm{e}}$, defined by:

iterative cycle and is defined by:

activated element in each construction step defined by:

overall balance by satisfying the compatibility conditions, boundary conditions and constitutive relationships.

This iterative scheme involves the stress state evaluation at each iterative cycle. Then, in each element, the increment of stress vector $\left(\Delta \sigma^{k}\right)$ is obtained by doing:

function in order to represent the yield and failure functions, there is no hardening during the plastic flow. In accordance with the elastic plasticity formulation, the constitutive matrix $\left(D_{t}\right)$ can be written as: where $D_{e}$ is the elastic constitutive matrix (Nogueira 2010); and respectively, $b_{e}$ and $\mathbf{a}$ are the gradient of the potential plastic function $(G)$ and the yield function $(F)$

$$
F=\sqrt{I_{2 D} K^{2}+(a \operatorname{sen} \varphi)^{2}}-\frac{I_{1}}{3} \operatorname{sen} \varphi-c \cos \varphi
$$

defined according to the modified MohrCoulomb criterion as (Oliveira 2006): where c is the cohesion; $\phi$ is the frictional angle; and $\mathrm{K}$ is a function of the Lode angle $(\theta)$ and the transition angle $\left(\theta_{\mathrm{T}}\right), \mathrm{I}_{1}$ and $\mathrm{I}_{2 \mathrm{D}}$ are stress inavri- ants. The transition angle and the constant $a$ are used in order to treat the vertex and apice singularities of the original Mohr-Coulomb criterion. The potential plastic function $(\mathrm{G})$ is equal to the yield function $(\mathrm{F})$, except for changing the frictional angle by the dilatant angle $(\psi)$.

\section{Hillside mining waste disposal dump - ascendant method}

This item describes the numerical simulation of a hillside mine waste disposal dump, which was built by the ascending method. The main goal of this simulation is to study the mechanical behavior of the dump in static equilibrium, under a plane strain condition and mounted on a deformable foundation, highlighting the surcharge aspect related to the geometric configuration. 
The dump construction was simulated in seven steps (one step per bench). Each construction step contains two layers released material. Figure 2 shows the typical finite element mesh adopted (2331 nodal points, 720 isoparametric quadrilateral quadratic elements (Q8) and 28 isoparametric triangular quadratic elements (T6), Nogueira, 2010), which has a varied foundation slope angle (i) and a general slope angle $(\alpha)$.
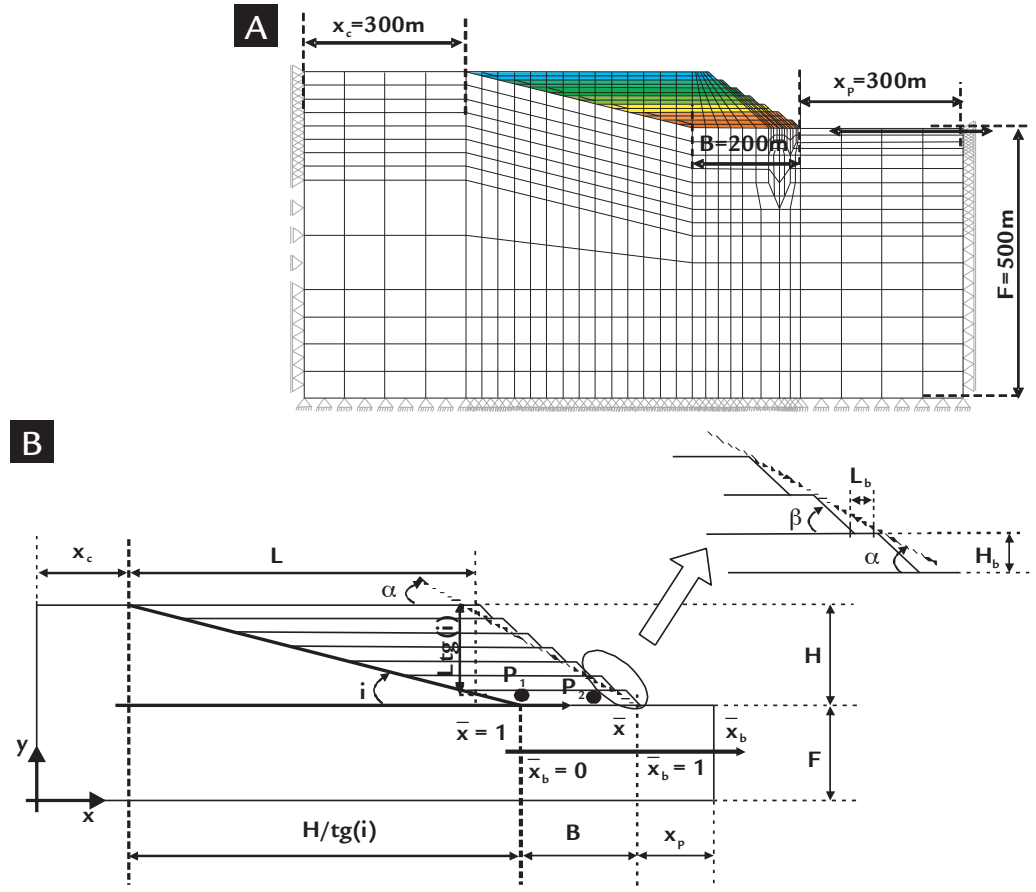

In order to verify the influence of the geometric parameters on mechanical behavior of the dump, four geometrical configurations were defined as indicated in Table 1 , by considering as

\begin{tabular}{c|c|c|c|c|c|c}
\hline \multicolumn{2}{c|}{ Foundation } & \multicolumn{2}{c|}{ Fill } & Identification & $\begin{array}{c}\mathbf{L} \\
(\mathbf{m})\end{array}$ & $\begin{array}{c}\text { Volume } \\
\left(\mathbf{m}^{\mathbf{3}}\right)\end{array}$ \\
\hline Slope & $\mathbf{i ( { } ^ { \circ } )}$ & $\alpha\left(^{\circ}\right)$ & $\beta\left(^{\circ}\right)$ & & 625 & 43313 \\
\hline $1: 7$ & 8.5 & 20 & 26 & SS17 & 731 & 48910 \\
\hline $1: 7$ & 8.5 & 30 & 43 & SM17 & 341 & 28429 \\
\hline $1: 4$ & 14.0 & 20 & 26 & MS14 & 448 & 34027 \\
\hline $1: 4$ & 14.0 & 30 & 43 & MM14 & 448 \\
\hline
\end{tabular}

constant: the dump height $(\mathrm{H})$ of $105 \mathrm{~m}$, the bench height $\left(\mathrm{H}_{\mathrm{b}}\right)$ of $15 \mathrm{~m}$, the berm width $\left(\mathrm{L}_{\mathrm{b}}\right)$ of $10 \mathrm{~m}$, while varying the foundation slope angle (i) from $8.5^{\circ}$ to $14^{\circ}$ and the general slope angle $(\alpha)$ $\phi=35^{\circ} ; \psi=35^{\circ} ; \theta_{\mathrm{T}}=28^{\circ}$ and $\mathrm{a}=15 \%$. The foundation material was represented by the following parameters: $\mathrm{E}_{2}=5 \mathrm{E}_{1}$ (in order to represent a deformable foundation in comparison to the dump material) and $v=0.1$.

Figure 3 illustrates the horizontal

$$
\begin{gathered}
\mathrm{I}_{\mathrm{h}}=u(m) \mathrm{E}_{2} /\left(\gamma \mathrm{H}^{2}\right) \\
\mathrm{I}_{v}=v(m) E_{2} /\left(\gamma \mathrm{H}^{2}\right) \\
\bar{x}=\left(x-x_{c}\right) /(H / \text { tgi })
\end{gathered}
$$

Figure 2

Analyzed dumps (Teixeira, 2011).

A) Finite element mesh.

B) Geometric parameter of the dump.

from $20^{\circ}$ to $30^{\circ}$. These variations led to a dump with a bench slope angle $(\beta)$ ranging from $26^{\circ}$ to $43^{\circ}$. Figure 2 shows geometric parameters that define the simulated dumps.

Table 1

Geometric parameters.

(u) and vertical (v) displacement variation throughout the foundation surface at the end of construction process, in terms of the horizontal $\left(\mathrm{I}_{\mathrm{h}}\right)$ and vertical $\left(\mathrm{I}_{\mathrm{v}}\right)$ displacement factor and the normalized horizontal distance $(\overline{\mathrm{x}})$, defined, according to Poulos and Davis (1972), as:
The modeling materials (waste dump and foundation) were considered homogeneous and isotropic. The following parameters were adopted in order to represent the constitutive behavior of the dump material considering an associate plasticity: $\mathrm{E}_{1}=35 \mathrm{MPa} ; \mathrm{v}=0.3 ; \gamma=22 \mathrm{kN} / \mathrm{m}^{3} ; \mathrm{c}=100 \mathrm{kPa} ;$ where, according to Figure 2, $\mathrm{x}$ is the horizontal coordinate of a generic point at the foundation surface; $\mathrm{H}$ is the dump height; $\mathrm{x}_{\mathrm{c}}$ is the horizontal length beyond the crest of the foundation slope; and $i$ is the foundation slope angle. $\mathrm{E}_{2}$ is the Young modulus of the foundation and $\gamma$ is the selfweight of the dump. The null normalized horizontal distance corresponds to the vertical passing at the crest of the founda- 
Figure 3

Displacement factor on foundation surface.

A) Horizontal displacement factor. B) Vertical displacement factor.

from the crest to the toe of the foundation slope, independent of the configuration. Its maximum value varies from $25 \%$ to $30 \%$ of the normalized horizontal distance (near the crest of the foundation). A signal changing to a normalized horizontal displacement of around $80 \%$ is verified.

The vertical displacement (Figure 3B) tends to increase (negatively) from the crest to the toe of the foundation slope, independent of the configuration. The maximum value coincides with the point where the horizontal displacement changes the signal, i. e., around $80 \%$ normalized horizontal distance (near the

where, according to Figure 2, $\mathrm{x}_{\mathrm{p}}$ is the length beyond of dump's toe and $\mathrm{B}$ is the

Figure 4

Vertical displacement factor at the base of the dump.

It can be seen that independent of configuration, the vertical displacement factor decreases in the dump's toe direction, being maximum value at the toe of the foundation slope. The highest vertical displacement is verified in dumps SM17 and MM14 which present the steepest general slope angles.

Figure 5 illustrates the stress path

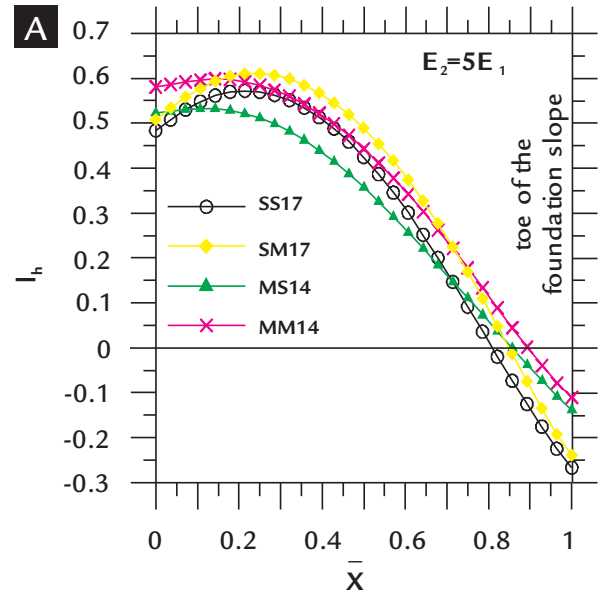

toe of the foundation). The vertical displacement factor is most affected by the dump's configuration than the horizontal displacement factor.

The volume of the dump depends on the foundation slope angle (i) and the general slope angle $(\alpha)$, since the base length of the dump (B) was made constant in all configurations. So, the volume of the dump MS14, with the smoothest general slope angle $\left(\alpha=20^{\circ}\right)$ built on a foundation with a moderate slope angle $\left(\mathrm{i}=14^{\circ}\right)$, is lower than the volume of the dump SM17, with the steepest general slope angle $\left(\alpha=30^{\circ}\right)$ built on a foundation with

$$
\overline{\mathrm{x}}_{\mathrm{b}}=\left(\mathrm{x}-\mathrm{x}_{\mathrm{c}}-(\mathrm{H} / \text { tgi })\right) /\left(\mathrm{B}+\mathrm{x}_{\mathrm{p}}\right)
$$

dump's base length. In this case, the normalized horizontal distance is null at the

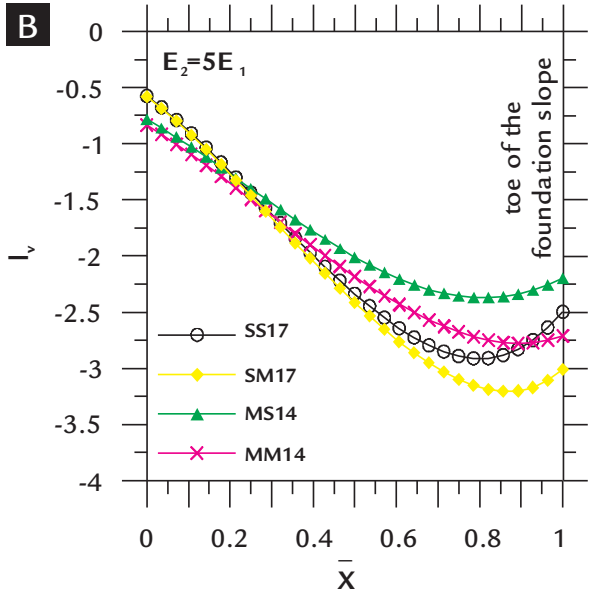

a smooth slope angle $\left(\mathrm{i}=8^{\circ}\right)$. Due to this, dump SM17 presents the highest vertical displacement factor.

Dump MM14, which has the steepest general slope angle $\left(\alpha=30^{\circ}\right)$ and was built on the steepest foundation (i=14), presents the highest horizontal displacement factor as expected. Then, the construction of steep dumps is not feasible, due to cinematic constraints and shear strength limitations.

The vertical displacement factor $\left(\mathrm{I}_{\mathrm{v}}\right)$ throughout the dump's base is presented in Figure 4 in terms of normalized horizontal distance $\left(\bar{x}_{\mathrm{b}}\right)$ defined as:

toe of the foundation slope and unitary $300 \mathrm{~m}$ distant from the dump's toe $\left(\bar{x}_{\mathrm{b}}=0.4\right)$.

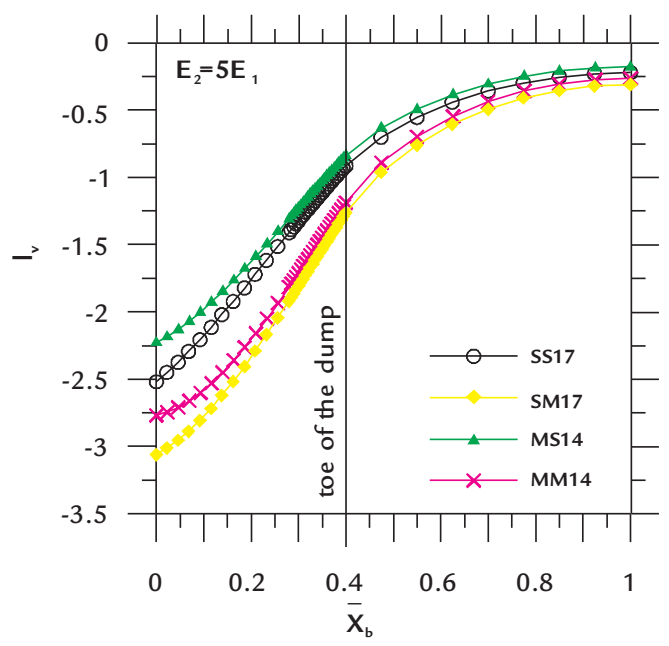

(during the constructive process) in terms of the stress invariants $\left(\mathrm{I}_{2 \mathrm{D}}\right.$ and $\left.\mathrm{I}_{1} / 3\right)$ at two specific points $\left(\mathrm{P}_{1}\right.$ e $\left.\mathrm{P}_{2}\right)$ located in the first dump layer. The $\mathrm{P}_{1}$ point is located near the toe of the foundation slope while the $\mathrm{P}_{2}$ point is located near the toe of the dump.

The stress path followed by the $\mathrm{P}_{1}$ point tends toward the $\mathrm{K}_{0}$ line, since this point is located at a position that leads to a confined compression. Related to $\mathrm{P}_{2}$ point, a deviation from $\mathrm{K}_{0}$ line to $\mathrm{K}_{\mathrm{f}}$ line is observed. The steepest general slope angle (dumps SM17 and MM14), reaches the $\mathrm{K}_{\mathrm{f}}$ line, indicating high shear strength mobilization.

Figure 6 illustrates the mobilization of the shear strength in dump's body, in terms of the stress ratio level SRL, defined as: 


$$
S R L=\sqrt{I_{2 D} K^{2}+(a \operatorname{sen} \phi)^{2}} /\left(\frac{I_{1}}{3} \operatorname{sen} \phi+c \cos \phi\right)
$$

The stress ratio level indicates the failure level proximity. Thus, when all available shear strength is mobilized the stress ratio level equals to the unit.

The stress states developed in dumps with a general slope angle $(\alpha)$ of $30^{\circ}$ and a bench slope angle $(\beta)$ of $43^{\circ}$ mobilize all shear strength available
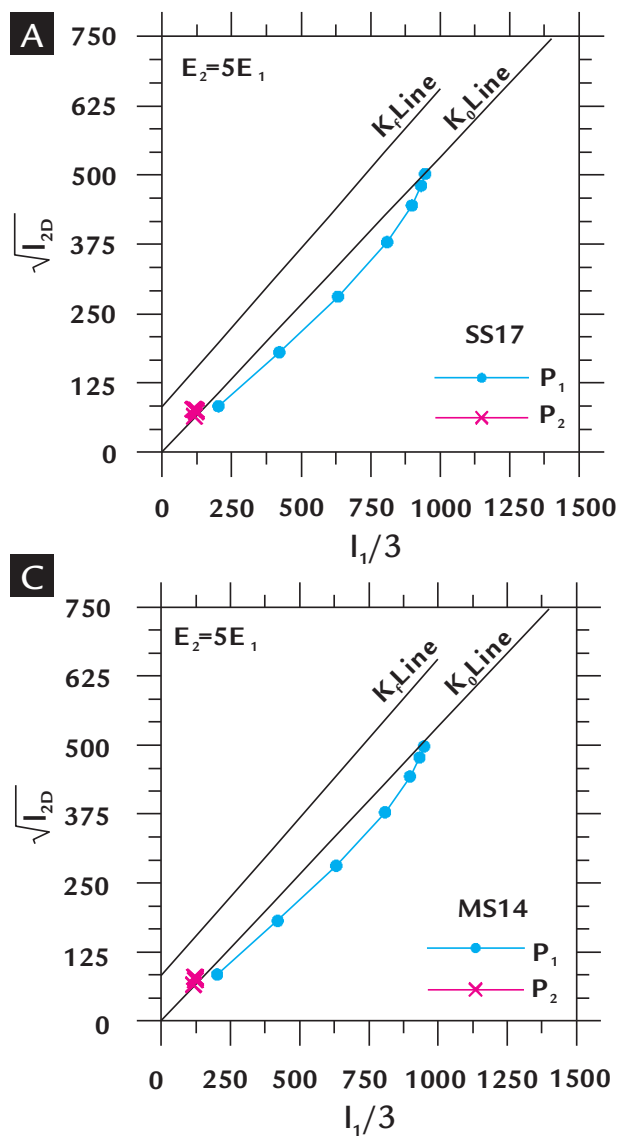

near the toe of these dumps (see detail at Figure 6). One can conclude that these configurations should be avoided and the bench slope angle should be decreased in order to prevent the general failure throughout the dump's toe. This can be reached by increasing the berm width.

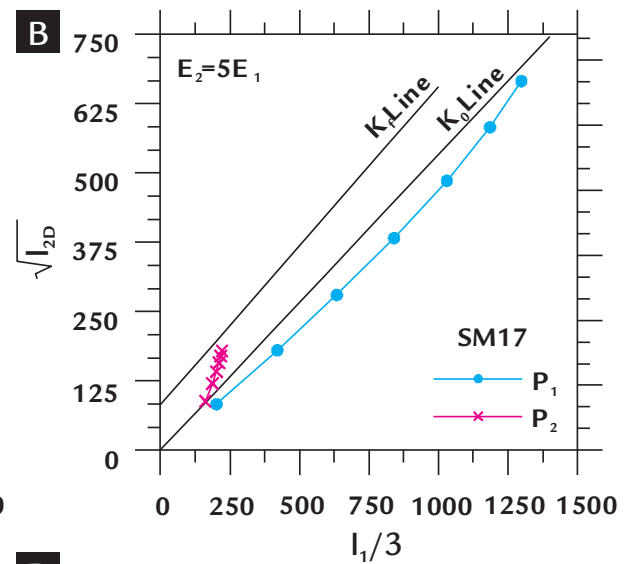

D

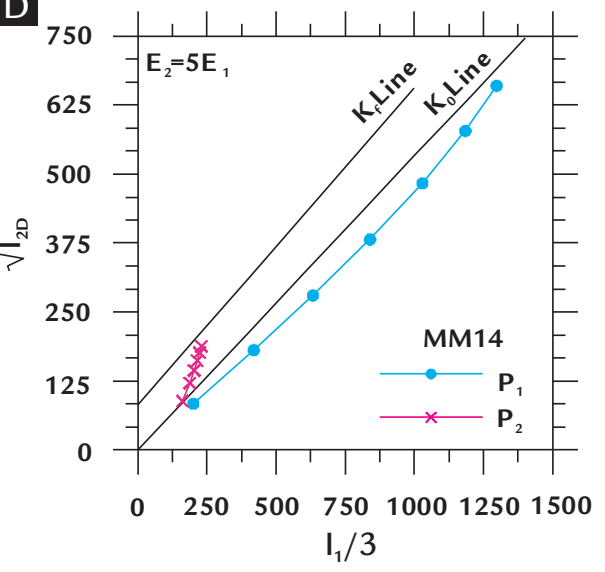

In all presented analyses, the berm width was made constant and equal to $10 \mathrm{~m}$. It was not possible to guarantee the stability of dumps SM17 and MM14, at least in the light of stress-strain analysis by using the elastic perfectly plastic constitutive model based on modified MohrCoulomb criterion.
Figure 5

Stress path at $\mathrm{P}_{1}$ and $\mathrm{P}_{2}$ points.
A) SS17.
B) SM17.
C) MS14.
D) MM14.
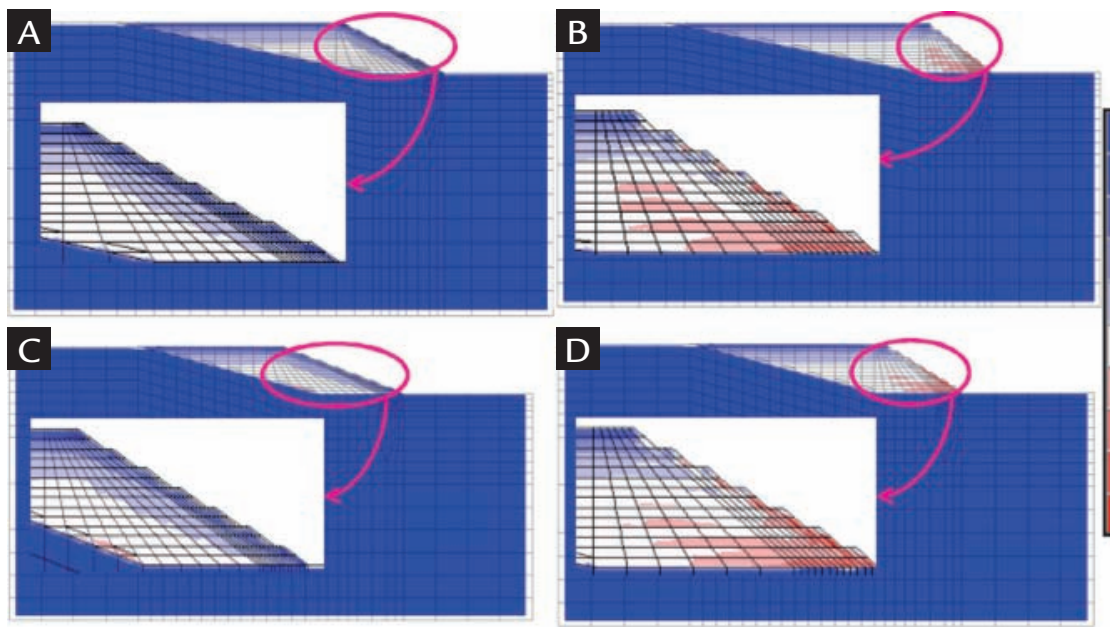

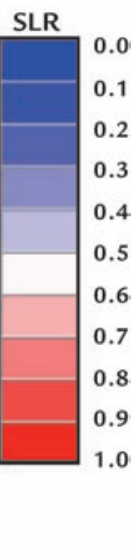

Figure 6

Stress ratio level (SLR).

A) Dump SS17.

B) Dump SM17

C) Dump MS14.

D) Dump MM-14.

\section{Conclusion}

The presented results illustrate the importance of numerical simulation by FEM for the construction of mine waste dumps. By stress-strain-strength analysis is possible to set/check the geometrical parameters, such as bench height, bench slope angle and berm width, in function of the mobilized shear strength even by using few constitutive parameters. Parametric 
studies can be performed easily with the computer program ANLOG for a wide

\section{Acknowledgments}

The authors are grateful for the financial support received by CAPES, variety of geometric configurations and materials, in order to provide support for the definition of requirements to be applied to projects for mine waste dumps.

\section{References}

ABBO, A. J. \& SLOAN, S. W. A smooth hyperbolic approximation to the MohrCoulomb yield criterion. Computers and Structures, v. 54, n. 3, p. 427-441, 1995.

BATHE, K. J. Finite element procedures in engineering analysis. Prentice-Hall Inc, 1982.

CRISFIELD, M. Non-linear finite element analysis of solids and structures. John Wiley and Sons, 1991.

NAYLOR, D. J., PANDE, G. N., SIMPSON, B., TABB, R. Finite Element in Geotechnical Engineering. Pineridge Press, 1981.

NOGUEIRA, C. L. ANLOG's User Guide. Department of Mine Engineering, Universidade Federal de Ouro Preto (UFOP), 2010. (In Portuguese).

NOGUEIRA, C. L. Non linear analysis of excavation and fills. Department of Civil Engineering, Pontifícia Universidade Católica do Rio de Janeiro (PUC-Rio), 1998. (DSc. Thesis). (In Potuguese).

OLIVEIRA, R. R. V. Elastoplastic analyses of reinforced soils problems by FEM. Department of Civil Engineering, Universidade Federal de Ouro Preto (UFOP), 2006. (MSc. Thesis). (In Portuguese).

POULOS, H. G., DAVIS, E. H. Elastic solution for soil and rock mechanics. John Willey Ed., 1972.

SLOAN, S. W., BOOKER, J. R. Removal of singularities in Tresca and MohrCoulomb yield criteria. Comunications in Applied Numerical Methods, v. 2, p. 173-179, 1986.

TEIXEIRA, M. B. Numerical study of mechanical behavior of mine waste dump. Ouro Preto: Department of Mine Engineering, Universidade Federal de Ouro Preto (UFOP), 2011. (MSc. Thesis). (In Portuguese).

TEIXEIRA, M. B., NOGUEIRA, C. L., VALVERDE, N. N. Parametric study of mechanical behaviour of mine waste dump by FEM. In: CILAMCE - IBERO LATIN AMERICAN CONFERENCE ON COMPUTATIONAL METHODS IN ENGINEERING, Ouro Preto, cdrom, 2011. (In Portuguese).

MATA, C., GUIMARÃES, L. J. N., LEDESMA, A., GENS, A., OLIVELLA, S. A Hydro-Geochemical analysis of the saturation process with salt water of a bentonite crushed granitic rock mixture in an engineered nuclear barrier. Engineering Geology, v.81, p. 227-245, 2005.

GUIMAR ÂES, L. J. N., GENS, A., OLIVELLA, SEBASTIÀ. Coupled thermohydro-mechanical and chemical analysis of expansive clay subjected to heating and hydration. Transport in Porous Media, v. 66, p. 341-372, 2007.

SILVA, J. C. Modeling and numerical simulation of two-phase flow and multicomponent transport in porous media interact with thermo-chemical. Department of Civil Engineering, Pontifícia Universidade Católica of Rio de Janeiro (PUC-Rio), 2004. (DSc. Dissertation). (In Portuguese).

Artigo recebido em 31 de outubro de 2011. Aprovado em 10 de setembro de 2012. 